\title{
Effects of tamoxifen on the fertility of male rats
}

\author{
M. K. Gill-Sharma, K. Gopalkrishnan, N. Balasinor, P. Parte, \\ S. Jayaraman and H. S. Juneja* \\ Institute for Research in Reproduction (ICMR), Parel, Bombay 400 012, India
}

\begin{abstract}
The effects of oral administration of tamoxifen (a synthetic non-steroidal anti-oestrogen) at doses of 40,200 or $400 \mu \mathrm{g} \mathrm{kg}^{-1}$ day $^{-1}$ on the circulating concentrations of LH, FSH, prolactin, testosterone and oestradiol, weights of pituitary, testes, secondary sex organs and the fertility of adult male rats were determined. The drug was administered per os daily, for up to 90 days. The fertility of rats treated with tamoxifen for $60,70,80$ or 90 days was assessed by allowing them to mate with normal female rats of proven fertility. Tamoxifen at $40 \mu \mathrm{g} \mathrm{kg}^{-1} \mathrm{day}^{-1}$ reduced concentrations of testosterone in plasma but had no affect on $\mathrm{LH}, \mathrm{FSH}$, prolactin and oestradiol concentrations, and the weights of pituitary, testes, epididymides, ventral prostate and seminal vesicles. Tamoxifen at $40 \mu \mathrm{g} \mathrm{kg}^{-1}$ day $^{-1}$ reduced potency, fecundity, the number of implantation sites, the fertility index and litter size. Tamoxifen at 200 and $400 \mu \mathrm{g} \mathrm{kg}^{-1}$ day $^{-1}$ reduced the concentrations of LH and testosterone in plasma and the weights of testes and secondary sex organs compared with controls. Tamoxifen at $400 \mu \mathrm{g} \mathrm{kg}^{-1}$ day $^{-1}$ was most effective in reducing the number of viable pups, the litter size $(\leqslant 1)$ and the fecundity $(20 \%)$. The potency of treated rats (a measure of the presence of an ejaculate) was significantly decreased when compared with controls, but copulation was apparently not affected as mated female rats showed a constant dioestrous phase. Histology of the testes revealed disorganization of the cytoarchitecture of the tubules with obliterated lumen. All the parameters affected by tamoxifen at $200 \mu \mathrm{g} \mathrm{kg}^{-1}$ day $^{-1}$ returned to normal values when tamoxifen was withdrawn for 90 days.
\end{abstract}

\section{Introduction}

The biological effects of tamoxifen, a synthetic non-steroidal anti-oestrogen, are complex and range from complete oestrogen antagonism to pure oestrogen agonism depending upon its concentration, the sex of the animal and the target organ. In humans and rats, tamoxifen is predominantly antioestrogenic with residual oestrogenic activity (Furr and Jordan, 1984).

The hypothalamus plays a crucial role in the maintenance of spermatogenesis by controlling the secretion of $\mathrm{LH}$ and FSH from the pituitary via $\mathrm{GnRH}$ (Schally et al., 1972). Testosterone and oestradiol are involved in the feedback regulation of $\mathrm{GnRH}$ synthesis and release via a long-loop feedback mechanism (Kalra and Kalra, 1983). Receptors for oestradiol are present in the hypothalamus (McEwen, 1975; Kato, 1977), pituitary (Muldoon, 1977), epididymides (Kamal et al., 1985; Tekpetey and Amann, 1988), Leydig cells and Sertoli cells (Van BeurdenLamers et al., 1974; Nakhla et al., 1984). Oestradiol receptors in the Leydig and Sertoli cells presumably play an important role in the paracrine regulation of spermatogenesis (Skinner, 1991). The hypothalamus, pituitary, epididymis and the Sertoli and
Leydig cells are important components of the male reproductive system. The contention that tamoxifen with its intrinsic oestrogen antagonist-agonist activities may interfere with male fertility is reasonable. In fact, tamoxifen is anti-gonadotrophic in male rats (Harper and Walpole, 1967). Daily administration of tamoxifen to male rats for 3-6 months reduces the weights of testes, accessory sex glands and arrests spermatogenesis (Furr et al., 1979; Wantanabe et al., 1980). Tamoxifen reduces testosterone production by Leydig cells in vitro (Lin et al., 1981); concentrations of $\mathrm{LH}$ and testosterone in plasma are significantly reduced following treatment with tamoxifen (Bartke et al., 1978), and plasma concentrations of $\mathrm{LH}$ and testosterone are increased in oligozoospermic patients responding to tamoxifen therapy (Willis et al., 1977; Vermeulin and Comhaire, 1978; Noci et al., 1985; Ain Melk et al., 1987). Despite the fact that tamoxifen has been available for two decades and its biochemical, pharmacological and toxicological effects have been documented, no systematic attempt has been made to evaluate the effect of tamoxifen on male fertility as with clomiphene citrate, a nonsteroidal anti-oestrogen structurally related to tamoxifen (Nelson and Patanelli, 1962; Roy et al., 1964; Kalra and Prasad, 1967; Heller and Heller, 1970; Flickinger, 1977). The study reported here describes the temporal effect of different doses of tamoxifen on plasma hormonal profiles, tissue weights and reproductive performances of male rats. 


\section{Materials and Methods}

\section{Animals}

Randomly bred male and female Holtzman strain rats were maintained at a temperature of $22-23^{\circ} \mathrm{C}$, humidity $50-55 \%$, and lighting cycle of $14 \mathrm{~h}$ light: $10 \mathrm{~h}$ dark. Commercial rat pellets and water were available ad libitum. Seventy-five-day-old male rats and ninety-day-old female rats of proven fertility were used.

\section{Tamoxifen}

Tamoxifen citrate tablets containing $10 \mathrm{mg}$ of tamoxifen were obtained from Lyka (Bombay). The drug was suspended uniformly in water by sonication and administered daily, per os, between 10:00 and 12:00 $\mathrm{h}$ via a rat feeding tube.

\section{Mating studies}

The mating design was either 1 male $\times 1$ female or $I$ male $\times 3$ females. Female rats were housed with treated or control male rats on the evening of pro-oestrus. As it was difficult to obtain a large number of female rats at pro-oestrus in a single batch, the male rats were exposed to pro-oestrous females within \pm 1 day of the treatment schedule. The occurrence of mating was confirmed by the presence of a copulatory plug or spermatozoa in the vaginal smear on the following morning.

\section{Experimental protocol}

The study was designed to evaluate the reproductive performance of male rats treated with three different doses of tamoxifen. The male rats were assigned to four groups of ten rats each and received either saline or 40,200 and $400 \mu \mathrm{g}$ tamoxifen $\mathrm{kg}^{-1}$ day ${ }^{-1}$, respectively. Each group of rats was allowed to mate with female rats ( $\mathrm{I}$ male $\times 3$ females) after 60 , 70,80 and 90 days of tamoxifen administration. Inseminated rats were caged individually and observed during the ensuing pregnancy. Normal delivery occurred between day 21 and day 22 of pregnancy. Litter size and the viability of the pups were recorded. The rats were killed within a few hours after delivery or on day 23 of pregnancy, if they failed to produce young. Ovaries were examined for corpora lutea, and uterine horns were examined for number of implantation sites and resorbed fetuses. Female rats that failed to show a vaginal plug or spermatozoa in the vaginal smears were monitored for oestrous cyclicity for a further 10 days. Rats that showed continuous dioestrus for at least 1 week were considered pseudopregnant. The following parameters were determined.

Potency. The ability of male rats to inseminate females was expressed as the ratio of female rats inseminated to the number of female rats exposed for mating $\times 100$.

Fertility index. The index of the ability of spermatozoa to fertilize ova was expressed as the ratio of the number of implantation sites to the number of corpora lutea (per two ovaries).
Percentage fecundity. The measure of the ability of male rats to sire viable pups was expressed as the ratio of the number of males siring at least one viable pup to the total number of males exposed for mating $\times 100$. The loss in fecundity indicated complete loss in the ability of spermatozoa to fertilize ova.

Autopsy of animals. The control and treated male rats were killed by decapitation. Blood from the trunk was allowed to clot at $4^{\circ} \mathrm{C}$ overnight. Serum was collected by centrifugation at $800 \mathrm{~g}$ for $20 \mathrm{~min}$ and stored frozen at $-300^{\circ} \mathrm{C}$ for radioimmunoassay of $\mathrm{LH}, \mathrm{FSH}$, prolactin, testosterone and oestradiol. Testes, pituitary gland and accessory sex organs were collected from each rat. The organs were weighed on a torsion balance. Plasma was stored at $-30^{\circ} \mathrm{C}$ for radioimmunoassay of $\mathrm{LH}, \mathrm{FSH}$, prolactin, testosterone and oestradiol.

Histology of tissues. Testicular tissues were fixed in modified Karnovsky's fixative as modified by David et al. (1973), washed in $0.1 \mathrm{~mol}$ cacodylate buffer $1^{-1}$, post-fixed in $1 \%$ osmium tetroxide, dehydrated in an ascending series of acetone (30$100 \%$ ), embedded in Araldite and semi-thin sections were cut at $0.5 \mu \mathrm{m}$ intervals. The sections were stained with toluidine blue (E. Merck, Darmstadt) and observed under bright-field optics at $\times 40$ or $\times 100$. Sodium cacodylate, osmium tetroxide and Araldite were from Pelco International (Redding, CA).

Hormone assays. $\mathrm{LH}, \mathrm{FSH}$ and prolactin were assayed as described by Balasinor et al. (1992). The standard curve for LH (NIADDK-Rat-LH-RP-2) ranged from $10 \mathrm{pg}$ to $12.5 \mathrm{ng}$ per assay tube, and for FSH (NIADDK-Rat-FSH-RP-2) from $10 \mathrm{pg}$ to $12.5 \mathrm{ng}$ per assay tube. The inter- and intra-assay coefficients of variations were 9 and $6 \%$ for $\mathrm{LH}$, and $10 \%$ and $6 \%$ for $\mathrm{FSH}$ assays, respectively. The standard curve for prolactin (NIADDK-Rat-PRL-RP-3) ranged from $10 \mathrm{pg}$ to $25 \mathrm{ng}$ per assay tube. Interassay and intra-assay coefficients of variations for prolactin were 14 and $5 \%$, respectively. Testosterone and oestradiol were assayed as described by Juneja et al. (1991). The standard curves ranged from 3.9 to $500 \mathrm{pg}$ for testosterone, and from 5 to $200 \mathrm{pg}$ for oestradiol. Intra- and interassay coefficients of variation were 5.5 and $11 \%$ for testosterone, and 6 and $10 \%$ for oestradiol, respectively.

\section{Statistical analysis}

Hormone concentrations and tissue weights were subjected to analysis of variance. Significant difference between groups was determined using Duncan's multiple range test. The level of significance was set at $P \leqslant 0.05$. Data relating to implantation sites, potency and fertility index were subjected to non-parametric Kruskal-Wallis one-way ANOVA.

\section{Results}

Effect of tamoxifen on implantation sites, fertility index and litter size

$40 \mu \mathrm{g}$ tamoxifen $\mathrm{kg}^{-1}$ day $^{-1}$. The total number of implantation sites in female rats $(\mathrm{F})$ mated with males treated with tamoxifen for $60,70,80$ and 90 days $[F(60), F(70), F(80)$ and $\mathrm{F}(90)$ ] was significantly lower than that of controls, $\mathrm{F}(\mathrm{C})$ (Table 1 ). 
Table 1. Implantation sites, fertility index and litter size of female rats mated with tamoxifen-treated male rats

\begin{tabular}{|c|c|c|c|c|c|c|c|c|c|c|c|c|c|c|c|c|}
\hline \multirow{2}{*}{$\begin{array}{l}\text { Tamoxifen } \\
\left(\mu \mathrm{kg}^{-1} \mathrm{day}^{-1}\right)\end{array}$} & \multirow{2}{*}{$\begin{array}{l}\text { Mating } \\
\text { design } \\
\text { (male } \times \\
\text { female) }\end{array}$} & \multicolumn{5}{|c|}{ Implantation sites ${ }^{a}$} & \multicolumn{5}{|c|}{ Fertility index ${ }^{b}$} & \multicolumn{5}{|c|}{ Litter size } \\
\hline & & $\mathrm{F}(\mathrm{C})$ & $F(60)$ & $F(70)$ & $\mathrm{F}(80)$ & $\mathrm{F}(90)$ & $F(C)$ & $F(60)$ & $F(70)$ & $F(80)$ & $F(90)$ & $\mathrm{F}(\mathrm{C})$ & $F(60)$ & $F(70)$ & $\mathrm{F}(80)$ & $\mathrm{F}(90)$ \\
\hline \multirow[t]{2}{*}{$\begin{array}{c}40 \\
\langle n=5)\end{array}$} & $1 \times 3$ & $\begin{array}{c}180 \\
(11-15)\end{array}$ & $\begin{array}{c}59 \\
(0-14)\end{array}$ & $\begin{array}{c}56 \\
(0-14)\end{array}$ & $\begin{array}{c}38 \\
(0-10)\end{array}$ & $\begin{array}{c}80 \\
(0-13)\end{array}$ & $\begin{array}{c}0.97 \\
(0.73-1)\end{array}$ & $\begin{array}{c}0.31 \\
(0-1)\end{array}$ & $\begin{array}{c}0.31 \\
(0-1)\end{array}$ & $\begin{array}{c}0.25 \\
(0-1)\end{array}$ & $\begin{array}{c}0.53 \\
(0-1)\end{array}$ & $\begin{array}{c}11 \\
(7-14) \\
7^{*}\end{array}$ & $\begin{array}{c}3 \\
(0-14) \\
3^{*}\end{array}$ & $\begin{array}{c}4 \\
(0-13) \\
7^{*}\end{array}$ & $\begin{array}{c}2 \\
(0-10) \\
1^{*}\end{array}$ & $\begin{array}{c}5 \\
(0-11) \\
6^{*}\end{array}$ \\
\hline & & 62.96 & 34.03 & 33.50 & 26.30 & 39.11 & 61.46 & 32.57 & 32.50 & 28.27 & 42.11 & 65.02 & 30.23 & 34.20 & 27.30 & 37.96 \\
\hline $\begin{array}{l}200 \\
(n=10)\end{array}$ & $1 \times 1$ & $\begin{array}{c}130 \\
(10-14)\end{array}$ & $\begin{array}{c}87 \\
(0-13)\end{array}$ & $\begin{array}{c}54 \\
(0-14)\end{array}$ & $\begin{array}{c}30 \\
(0-10)\end{array}$ & $\begin{array}{c}45 \\
(0-12)\end{array}$ & $\begin{array}{l}1.0 \\
(1-1)\end{array}$ & $\begin{array}{r}0.64 \\
(0.14-1)\end{array}$ & $\begin{array}{c}0.44 \\
(0.15-1)\end{array}$ & $\begin{array}{c}0.27 \\
(0-0.8)\end{array}$ & $\begin{array}{c}0.41 \\
(0-1)\end{array}$ & $\begin{array}{c}10 \\
(6-14) \\
6^{*}\end{array}$ & $\begin{array}{c}6 \\
(0-13) \\
3^{*}\end{array}$ & $\begin{array}{c}5 \\
(0-14) \\
4^{*}\end{array}$ & $\begin{array}{r}1 \\
(0-4) \\
4^{*}\end{array}$ & $\begin{array}{c}4 \\
(0-12) \\
1^{*}\end{array}$ \\
\hline \multirow[t]{2}{*}{$\begin{array}{l}400 \\
(n=5)\end{array}$} & $1 \times 3$ & $\begin{array}{c}\mathbf{4 6 . 6 0} \\
180 \\
(11-15)\end{array}$ & $\begin{array}{c}\mathbf{3 1 . 3 8} \\
3 \\
(0-3)\end{array}$ & $\begin{array}{c}27.15 \\
0 \\
(0-0)\end{array}$ & $\begin{array}{c}16.25 \\
7 \\
(0-7)\end{array}$ & $\begin{array}{c}22.70 \\
10 \\
(0-9)\end{array}$ & $\begin{array}{c}\mathbf{4 4 . 7 1} \\
0.97 \\
(0.73-1)\end{array}$ & $\begin{array}{l}33.25 \\
0.02 \\
(0-0.23)\end{array}$ & $\begin{array}{c}\mathbf{2 7 . 7 5} \\
0.0 \\
(0-0)\end{array}$ & $\begin{array}{c}\mathbf{1 6 . 4 0} \\
0.04 \\
(0-0.5)\end{array}$ & $\begin{array}{c}23.65 \\
0.08 \\
(0-1)\end{array}$ & $\begin{array}{c}46.98 \\
11 \\
(7-14) \\
7^{*}\end{array}$ & $\begin{array}{c}29.79 \\
<1 \\
(0-3) \\
3^{*}\end{array}$ & $\begin{array}{c}27.20 \\
0 \\
(0-0) \\
0^{*}\end{array}$ & $\begin{array}{c}14.60 \\
<1 \\
(0-7) \\
7^{*}\end{array}$ & $\begin{array}{c}25.40 \\
<1 \\
(0-9) \\
1^{*}\end{array}$ \\
\hline & & 68.50 & 30.47 & 28.50 & 28.50 & 34.96 & 68.93 & 30.47 & 28.50 & 28.50 & 35.82 & 68.50 & 30.47 & 28.50 & 28.50 & 34.96 \\
\hline
\end{tabular}

\footnotetext{
${ }^{3}$ Total implantation sites per group, $n=$ number of male rats.

${ }^{b}$ Fertility index $=\frac{\text { Implantation sites }}{\text { Number of corpora lutea }}$ and is expressed as mean of the group.

Litter size is expressed as mean of the group; "Minimum viable litter size.

$F(C)$ : Female rats mated with control rats; $F(60,70,80,90)$ : Fernale rats mated with rats treated with tamoxifen for $60,70,80$ or 90 days

$V$ alues in parentheses indicate range of implantation sites per uterus, fertility index, or viable pups.

Values in bold type are mean rank values from Kruskal-Wallis one-way ANOVA.
}

The mean rank value of 62.96 for implantation sites in $\mathrm{F}(\mathrm{C})$ decreased significantly to $34.0,37.5,26.3$ and 39.11 in $F(60)$, $\mathrm{F}(70), \mathrm{F}(80)$ and $\mathrm{F}(90)$, respectively. The number of implantation sites per uterus ranged from 11 to 15 in controls, and between 0 and 14 in the females mated with males fed tamoxifen for 60 , 70,80 or 90 days.

The fertility index was 0.97 for $F(C)$ and ranged from 0.73 to $I$ in controls, and between 0 and $I$ in $F(60), F(70), F(80)$ and $F(90)$. The fertility index was significantly lower as indicated by a significant fall in mean rank value of fertility index in $F(C)$ from 61.46 to $32.57,32.50,28.27$ and 42.11 in the $F(60), F(70)$, $F(80)$ and $F(90)$ groups, respectively.

The size of the litter delivered by $F(C)$ was $I I$ and was significantly reduced in $F(60), F(70), F(80)$ and $F(90)$. The litter size for $F(C)$ ranged between 7 and 14, whereas for treated groups it ranged from 0 to 14 . The minimum number of viable pups delivered by $F(C)$ was seven, whereas it was three, seven, one and six for $F(60), F(70), F(80)$ and $F(90)$, respectively.

$200 \mu \mathrm{g}$ tamoxifen $\mathrm{kg}^{-1} \mathrm{day}^{-1}$. The total number of implantation sites was significantly lower in $F(60), F(70), F(80)$ and $F(90)$ compared with that of $F(C)$. This was evident from a significantly lower mean rank value of implantation sites, in $\mathrm{F}(\mathrm{C})$ 46.60 and $31.38,27.15,16.25$ and 22.70 in $F(60), F(70), F(80)$ and $F(90)$, respectively. The number of implantation sites per uterus ranged between 10 and 14 in $F(C)$, and between 0 and 14 in $F(60), F(70), F(80)$ or $F(90)$.

The fertility index was 1.0 for $\mathrm{F}(\mathrm{C})$. It ranged from 0.14 to 1 , 0.15 to 1,0 to 0.8 and 0 to 1 in $F(60), F(70), F(80)$ and $F(90)$, respectively. The fertility index was significantly lower in females mated with tamoxifen-treated males as shown by the significantly lower mean rank values of fertility index of these groups compared with controls.

The size of the litter delivered by $\mathrm{F}(\mathrm{C})$ was ten. It ranged from 6 to 14,0 to 13,0 to 14,0 to 4 and 0 to 12 in $F(C), F(60)$, $F(70), F(80)$ and $F(90)$, respectively. The litter size was signifi- cantly smaller in female rats mated with tamoxifen-treated male rats as shown by a significantly lower mean rank value of litter size in treated groups compared with controls. The minimum number of pups delivered by $\mathrm{F}(\mathrm{C})$ was six, whereas it was three, four, four and one for $F(60), F(70), F(80)$ and $F(90)$, respectively.

$400 \mu \mathrm{g}$ tamoxifen $\mathrm{kg}^{-1} \mathrm{day}^{-1}$. There were fewer implantation sites in the groups of females mated with treated male rats compared with controls. The number of implantation sites was zero in $F(70)$ but was three, seven and ten in $F(60), F(80)$ and $F(90)$, respectively. The number of implantation sites per uterus ranged from 0 to 3 in $F(60)$, and 0 to 7 and 0 to 9 in $F(80)$ and $F(90)$, respectively.

The fertility index was close to zero in the treated groups.

Treatment with tamoxifen resulted in significantly fewer pups delivered by $F(60), F(70), F(80)$ and $F(90)$ compared with controls. No viable pups were delivered by $F(70)$. The litter size was zero or one in the treated group. The minimum number of viable pups delivered by $F(60), F(80)$ and $F(90)$ was three, seven and one, respectively.

\section{Effect of tamoxifen on the potency and fecundity of rats}

The potency and fecundity of male rats treated with tamoxifen was significantly lower than that of controls (Table 2). Tamoxifen at $400 \mu \mathrm{g} \mathrm{kg}^{-1} \mathrm{day}^{-1}$ was more effective than at $40 \mu \mathrm{g} \mathrm{kg}^{-1}$ day $^{-1}$ in suppressing potency and fecundity of rats.

\section{Effect of tamoxifen on tissue weights}

Tamoxifen did not affect the weights of testes, seminal vesicles, epididymides, ventral prostate glands and the pituitary glands at $40 \mu \mathrm{g} \mathrm{kg}^{-1}$ day $^{-1}$ for 90 days (Table 3). At 200 and $400 \mu \mathrm{g}$ tamoxifen $\mathrm{kg}^{-1}$ day ${ }^{-1}$ the weights of ventral prostate glands, seminal vesicles and epididymides were significantly lower than controls.

Downloaded from Bioscientifica.com at 04/26/2023 01:25:09PM 
Table 2. Effect of tamoxifen on the potency and fecundity of male rats

\begin{tabular}{|c|c|c|c|c|c|c|c|c|c|c|c|}
\hline \multirow{2}{*}{$\begin{array}{l}\text { Tamoxifen } \\
\left(\mu \mathrm{g} \mathrm{kg}^{-1} \text { day }^{-1}\right)\end{array}$} & \multirow{2}{*}{$\begin{array}{l}\text { Mating design } \\
(\text { male } \times \text { female) }\end{array}$} & \multicolumn{5}{|c|}{ Potency $^{a}$} & \multicolumn{5}{|c|}{ Fecundity ${ }^{b}$} \\
\hline & & $M(C)$ & $M(60)$ & $M(70)$ & $\mathrm{M}(80)$ & $\mathrm{M}(90)$ & $\mathrm{M}(\mathrm{C})$ & $M(60)$ & $\mathrm{M}(70)$ & $\mathrm{M}(80)$ & $\mathrm{M}(90)$ \\
\hline $\begin{array}{c}40 \\
(n=5)\end{array}$ & $1 \times 3$ & 100 & 60 & 46.6 & 27 & 53 & 100 & 60 & 60 & 60 & 60 \\
\hline $\begin{array}{l}200 \\
(n=10)\end{array}$ & $1 \times 1$ & 100 & 100 & 100 & 100 & 100 & 100 & 80 & 40 & 20 & 40 \\
\hline $\begin{array}{l}400 \\
(n=5)\end{array}$ & $1 \times 3$ & 100 & 67 & 13 & 27 & 29 & 100 & 20 & 0 & 20 & 20 \\
\hline
\end{tabular}

$\mathrm{M}(\mathrm{C})$ : Control males; $\mathrm{M}(60,70,80,90)$ : male rats treated with tamoxifen for $60,70,80$ or 90 days.

${ }^{\text {} P o t e n c y}=\frac{\text { Number of female rats inseminated }}{\text { Number of female rats exposed for mating }} \times 100$.
${ }^{\text {bFecundity }}=\frac{\text { Number of male rats siring at least one viable pup }}{\text { Number of males exposed for mating }} \times 100$.
$n=$ number of male rats.

Table 3. Tissue weights of rats after 90 days of tamoxifen treatment

\begin{tabular}{|c|c|c|c|c|c|c|c|c|}
\hline \multirow{3}{*}{$\begin{array}{l}\text { Tissues } \\
\text { Testes }(\mathrm{g})\end{array}$} & \multicolumn{8}{|c|}{ Tamoxifen $\left(\mu \mathrm{g} \mathrm{kg}^{-1}\right.$ day $\left.^{-1}\right)$} \\
\hline & \multicolumn{2}{|c|}{0} & \multicolumn{2}{|c|}{40} & \multicolumn{2}{|c|}{200} & \multicolumn{2}{|c|}{400} \\
\hline & $3.39 \pm$ & 0.19 & $3.43 \pm$ & 0.20 & $2.88 \pm$ & 0.55 & $2.83 \pm$ & 0.36 \\
\hline Epididymides (g) & $1.07 \pm$ & $\pm \quad 0.10$ & $1.13 \pm$ & 0.06 & $0.72 \pm$ & $0.17^{*}$ & $0.75 \pm$ & $0.15^{*}$ \\
\hline Seminal vesicles (mg) & $300 \pm$ & \pm 100 & $310 \pm$ & 40 & $150 \pm$ & $70^{*}$ & $160 \pm$ & $60^{*}$ \\
\hline Ventral prostate (mg) & 410 & \pm 100 & $440 \pm$ & 110 & $150 \pm$ & $80^{*}$ & $170 \pm$ & $90^{*}$ \\
\hline Pituitary (mg) & $7.95 \pm$ & $\pm \quad 1.10$ & $7.83 \pm$ & $=0.75$ & $7.50 \pm$ & 0.76 & $7.36 \pm$ & 1.03 \\
\hline Adrenals (mg) & $40 \pm$ & \pm 10 & $40 \pm$ & $=10$ & $40.70 \pm$ & 7.00 & $40 \pm$ & 10 \\
\hline
\end{tabular}

Values are expressed as means $\pm \mathrm{SD}$.

${ }^{*} P \leqslant 0.05$ (compared with controls).

\section{Effect of tamoxifen on plasma hormone concentrations}

Tamoxifen, at all doses tested, reduced testosterone concentrations significantly compared with saline treated controls (Table 4). FSH, prolactin and oestradiol concentrations were unaffected. Plasma LH was significantly lower after treatment with 200 and $400 \mu \mathrm{g}$ tamoxifen $\mathrm{kg}^{-1}$ day $^{-1}$ than in controls. Tamoxifen at $40 \mu \mathrm{g} \mathrm{kg}^{-1}$ day $^{-1}$ did not affect concentrations of $\mathrm{LH}$ in plasma. There were no significant changes in the serum profiles of $\mathrm{FSH}$, prolactin and oestradiol following tamoxifen treatment.

\section{Effect of tamoxifen on testicular histology}

The cytoarchitecture of the seminiferous tubules was disorganized in treated rats (Fig. 1). In the treated groups fewer tubules contained a lumen and the lumen of some tubules was filled with cellular debris. The disorganization of germ cells increased the intercellular space and there was loose intercellular contact within the germinal epithelium. This was predominantly seen in the basal compartment of the epithelium. Cells lying on the basement membrane, that is Sertoli cells, spermatogonia and preleptotene spermatocytes frequently appeared to be isolated from the neighbouring cells. The disorganization of the germinal epithelium after tamoxifen treatment was also shown by the occurrence of spermatocytes and predominantly premature spermatids in the tubular lumen. There was no significant change in tubular diameter. Leydig cells were well preserved and appeared normal.

\section{Reversibility of tamoxifen-induced effects}

Reversibility studies were performed with $200 \mu \mathrm{g}$ tamoxifen $\mathrm{kg}^{-1}$ day $^{-1}$. All the parameters affected by tamoxifen, weights of seminal vesicles, ventral prostate glands, epididymides, concentrations of $\mathrm{LH}$ and testosterone in plasma, potency, fecundity, fertility index and litter size were corrected after 90 days of drug withdrawal (Table 5).

\section{Discussion}

Tamoxifen is used extensively in the treatment of breast cancer and has been in clinical use for over two decades (Jordan Downloaded from Bioscientifica.com at 04/26/2023 01:25: ๑9pM 
Table 4. Plasma hormone profile after 90 days of tamoxifen administration in rats

\begin{tabular}{|c|c|c|c|c|}
\hline \multirow[b]{2}{*}{ Hormone } & \multicolumn{4}{|c|}{ Tamoxifen $\left(\mu \mathrm{g} \mathrm{kg}^{-1} \mathrm{day}^{-1}\right)$} \\
\hline & 0 & 40 & 200 & 400 \\
\hline $\mathrm{LH}\left(\mu \mathrm{g} \mathrm{I}^{-1}\right)$ & $\begin{array}{l}0.75 \pm 0.39 \\
(n=27)\end{array}$ & $\begin{array}{c}0.53 \pm 0.22 \\
(n=11)\end{array}$ & $\begin{array}{c}0.26 \pm 0.07^{*} \\
(n=9)\end{array}$ & $\begin{array}{c}0.18 \pm 0.03^{*} \\
(n=5)\end{array}$ \\
\hline $\mathrm{FSH}\left(\mu \mathrm{g} \mathrm{l^{-1 } )}\right.$ & $\begin{array}{c}7.52 \pm 2.12 \\
(n=27)\end{array}$ & $\begin{array}{c}7.13 \pm 1.05 \\
(n=11)\end{array}$ & $\begin{array}{c}7.84 \pm 2.15 \\
(n=9)\end{array}$ & $\begin{array}{c}9.90 \pm 2.21 \\
(n=5)\end{array}$ \\
\hline Prolactin $\left(\mu \mathrm{g} \mathrm{l}^{-1}\right)$ & $\begin{array}{c}15.57 \pm 8.68 \\
(n=24)\end{array}$ & $\begin{array}{c}13.83 \pm 7.56 \\
(n=8)\end{array}$ & $\begin{array}{c}9.10 \pm 2.84 \\
(n=9)\end{array}$ & $\begin{array}{c}8.55 \pm 7.00 \\
(n=5)\end{array}$ \\
\hline Testosterone $\left(\mu \mathrm{g} \mathrm{l^{-1 }}\right)$ & $\begin{array}{c}2.90 \pm 1.82 \\
(n=27)\end{array}$ & $\begin{array}{c}1.06 \pm 0.52^{*} \\
(n=11)\end{array}$ & $\begin{array}{c}0.95 \pm 0.52^{*} \\
(n=9)\end{array}$ & $\begin{array}{c}0.26 \pm 0.18^{*} \\
(n=5)\end{array}$ \\
\hline Oestradiol (ng $1^{-1}$ ) & $\begin{array}{c}50.39 \pm 19.26 \\
(n=28)\end{array}$ & $66 \begin{array}{c} \pm 27.08 \\
(n=11)\end{array}$ & $\begin{array}{c}59.05 \pm 15.48 \\
(n=8)\end{array}$ & $\begin{array}{c}37.21 \pm 15.70 \\
(n=5)\end{array}$ \\
\hline
\end{tabular}

Values are expressed as means \pm SD.

${ }^{*} P \leqslant 0.05$ (compared with controls).

$n=$ number of animals.
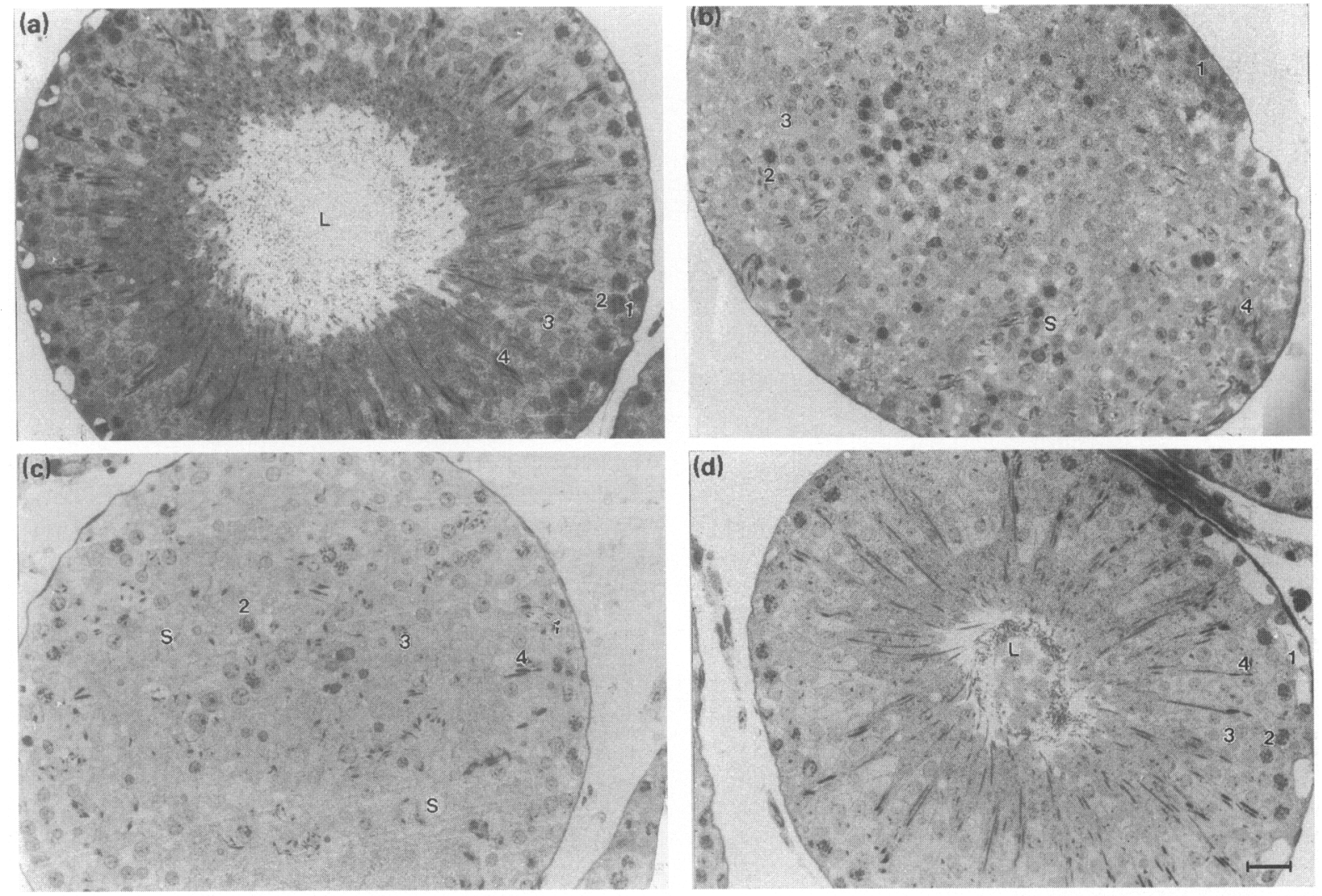

Fig. 1. Light micrographs of semi-thin sections $(0.5 \mu \mathrm{m})$ of (a) control rat testis showing normal spermatogenesis with tubular lumen (L), Sertoli cells (1), spermatocyte (2), round spermatid (3). and elongated spermatid (4). (b) Testis of rat treated with tamoxifen (200 $\mu \mathrm{g}$ $\mathrm{kg}^{-1}$ day $^{-1}$ ) showing disorganization of seminiferous tubular elements. The tubules show no lumen but more intercellular space (S). Note the presence of Sertoli cell (1), spermatocyte (2), round spermatid (3) and elongated spermatid (4). (c) Testis of rat treated with tamoxifen $\left(400 \mu \mathrm{g} \mathrm{kg}^{-1}\right.$ day $\left.{ }^{-1}\right)$ showing marked disorganization of germ cells in the seminiferous tubule. Note increase in the intercellular space (S). Sertoli cell (1), spermatocyte (2), round spermatid (3) and elongated spermatid (4) are seen. (d) Testis of rat after drug withdrawal of tamoxifen for 90 days showing normal spermatogenesis with tubular lumen (L), Sertoli cell (I), spermatocyte (2), round spermatid (3) and elongated spermatid (4). Scale bar represents $25 \mu \mathrm{m}$. 
Table 5. Reversal of tamoxifen-induced effects in rats

\begin{tabular}{|c|c|c|c|}
\hline $\begin{array}{l}\text { Affected } \\
\text { parameters }\end{array}$ & Control & $\begin{array}{c}\text { After } 90 \text { days } \\
\text { of tamoxifen } \\
\left(200 \mu \mathrm{kg}^{-1} \text { day }^{-1}\right) \\
\text { administration }\end{array}$ & $\begin{array}{l}\text { After } 90 \text { days } \\
\text { of drug } \\
\text { withdrawal }\end{array}$ \\
\hline \multicolumn{4}{|l|}{ Tissue weights } \\
\hline Epididymides (g) & $\begin{array}{c}1.01 \pm 0.20 \\
(n=30)\end{array}$ & $\begin{array}{c}0.72 \pm 0.17^{*} \\
(n=10)\end{array}$ & $\begin{array}{c}1.28 \pm 0.07 \\
(n=5)\end{array}$ \\
\hline Seminal vesicles (g) & $\begin{array}{c}0.34 \pm 0.07 \\
(n=30)\end{array}$ & $\begin{array}{c}0.15 \pm 0.08^{*} \\
(n=10)\end{array}$ & $\begin{array}{c}0.44 \pm 0.06 \\
(n=5)\end{array}$ \\
\hline Ventral prostate (g) & $\begin{array}{c}0.38 \pm 0.11 \\
(n=30)\end{array}$ & $\begin{array}{c}0.15 \pm 0.05^{*} \\
(n=10)\end{array}$ & $\begin{array}{c}0.56 \pm 0.26 \\
(n=5)\end{array}$ \\
\hline \multicolumn{4}{|l|}{ Plasma hormone profile } \\
\hline LH $\left(\mu \mathrm{g} 1^{-1}\right)$ & $\begin{array}{c}0.45 \pm 0.29 \\
(n=30)\end{array}$ & $\begin{array}{c}0.22 \pm 0.07^{*} \\
(n=10)\end{array}$ & $\begin{array}{c}0.49 \pm 0.12 \\
(n=5)\end{array}$ \\
\hline Testosterone $\left(\mu \mathrm{g} \mathrm{l}^{-1}\right)$ & $\begin{array}{c}4.06 \pm 1.80 \\
(n=30)\end{array}$ & $\begin{array}{c}0.64 \pm 0.16^{*} \\
(n=10)\end{array}$ & $\begin{array}{l}2.44 \pm 0.95 \\
\quad(n=5)\end{array}$ \\
\hline \multicolumn{4}{|l|}{ Mating characteristics } \\
\hline$\%$ fecundity & $\begin{array}{c}100 \\
(n=10)\end{array}$ & $\begin{array}{l}40 \\
(n=10)\end{array}$ & $\begin{array}{l}100 \\
(n=5)\end{array}$ \\
\hline Fertility index & $\begin{array}{c}0.97 \\
(n=10)\end{array}$ & $\begin{array}{c}0.44^{*} \\
(n=10)\end{array}$ & $\begin{array}{r}1.00 \\
(n=5)\end{array}$ \\
\hline Litter size & $\begin{array}{c}11.30 \\
(n=10)\end{array}$ & $\begin{array}{c}3.20^{* *} \\
(n=10)\end{array}$ & $\begin{array}{r}9.50 \\
(n=5)\end{array}$ \\
\hline
\end{tabular}

Values are means \pm SD.

$n=$ number of animals. "Significantly different from control group $\left(P \leqslant 0.05\right.$, students $t$ test). ${ }^{* *}$ Significantly different from controls $(P \leqslant 0.05$, Mann-Whitney $\mathrm{U}$ test).

and Murphy, 1990). It has few side effects, and has also been recommended for prophylactic treatment of women prone to breast cancer (Buckley and Goa, 1989). Tamoxifen has also been recommended for the treatment of oligozoospermia (Willis et al., 1977; Vermeulin and Comhaire, 1978; Noci et al., 1985; AinMelk et al., 1987), and gynaecomastia (Patterson et al., 1980; Parker et al, 1986), at doses ranging from 10 to $30 \mathrm{mg} \mathrm{day}^{-1}$.

In the study reported here, tamoxifen administered at $40 \mu \mathrm{g}$ $\mathrm{kg}^{-1}$ day $^{-1}$ for 90 days did not affect the weights of testes, accessory sex organs and the pituitary. It effected a reduction in the number of implantation sites, fertility index, litter size, fecundity and potency. Testosterone concentrations in plasma were lower than in controls, but there were no changes in concentrations of LH, FSH, prolactin and oestradiol. These results suggest that tamoxifen has a direct effect at the testicular level, probably on Leydig cells and inhibits testosterone production. This contention is supported by earlier observations that tamoxifen reduced testosterone production by Leydig cells in vitro (Lin et al., 1981). As the sperm fertilizing potential depends on circulating testosterone (Orgebin-Crist et al, 1975), a lower concentration of circulating testosterone may have affected the sperm fertilizing potential.

Tamoxifen at $200 \mu \mathrm{g} \mathrm{kg}^{-1}$ day ${ }^{-1}$ reduced the weights of seminal vesicles, ventral prostate glands and epididymides. It also caused a significant reduction in concentrations of $\mathrm{LH}$ and testosterone, without affecting concentrations of $\mathrm{FSH}$, prolactin and oestradiol. If the effects of tamoxifen were limited to testicular tissue causing 'chemical castration', lower testosterone concentrations would have activated regulatory 'long-loop' feedback mechanisms to increase the secretion of LH. Our finding of a decrease, rather than an increase, in circulating $\mathrm{LH}$ suggests that $200 \mu \mathrm{g}$ tamoxifen acted as an 'oestrogen' agonist at the hypothalamus-pituitary axis by inhibiting the secretion of LH by the pituitary. The reduction in LH may have accentuated the reduction in weights of accessory sex organs by further decreasing circulating concentrations of testosterone by reducing synthesis of testosterone by Leydig cells. The possibility that weights of accessory sex glands were low owing to oestrogen 'agonist' activity of tamoxifen cannot be ruled out, as oestradiol is known to affect the weights of accessory sex organs by direct action (Robaire et al., 1979). Tamoxifen at $200 \mu \mathrm{g}$ also reduced the number of implantation sites, fertility index, litter size, fecundity and potency.

Although plasma testosterone, fertility index and litter size of rats treated with 40 or $200 \mu \mathrm{g}$ tamoxifen for 90 days did not differ significantly from each other, they were significantly less and more comparable with controls or with rats treated with $400 \mu \mathrm{g}$ tamoxifen, respectively. The data indicate that reduction in fertility index and litter size paralleled the lower concentrations of testosterone. A pronounced reduction in concentrations of testosterone in plasma in rats administered $400 \mu \mathrm{g}$ tamoxifen was accompanied by a pronounced reduction in fertility index and litter size compared with that of controls or groups receiving 40 or $200 \mu \mathrm{g}$ tamoxifen $\mathrm{kg}^{-1}$ day ${ }^{-1}$. It is inferred that sperm fertilization potential is sensitive to concentrations of testosterone in plasma and is impaired on its reduction. The sperm fertilizing potential is virtually zero in the presence of low circulating testosterone. 
Tamoxifen at $400 \mu \mathrm{g} \mathrm{kg}^{-1}$ day $^{-1}$ reduced the fertility index to nearly zero and adversely affected the insemination capacity of male rats. Tamoxifen at this dose induced almost complete sterility in treated rats and there was a marked reduction in the number of viable pups sired by a male.

The potency of male rats treated with $400 \mu \mathrm{g}$ tamoxifen for $60,70,80$ or 90 days was adversely affected. It was not clear whether loss in potency was concomitant with loss in libido. Most of $F(60), F(70), F(80)$ and $F(90)$ failed to show a vaginal plug or presence of spermatozoa in vaginal smears. The vaginal smears on subsequent days showed that these females were at persistent dioestrus, thereby indicating that mating had occurred. Thus, it could be concluded that tamoxifen at $400 \mu \mathrm{g}$ impaired fertility of male rats without completely ablating mating behaviour. Concentrations of testosterone and LH were markedly reduced as were the weights of testes, seminal vesicles, ventral prostate glands and epididymides. Pituitary weights were not affected. Testosterone deprivation is known to affect potency of rats (Orgebin-Crist et al., 1975). The ability to mate may have been maintained owing to oestradiol concentrations (Sodersten, 1979) or owing to low plasma testosterone which was sufficient for normal mating behaviour but not for maintenance of fertility potential of spermatozoa (Bhasin et al., 1988).

Tamoxifen-treated male rats, irrespective of dose of the drug administered, showed variations in individual fecundity. Some of the rats that were completely sterile on days 60 and 70 of tamoxifen treatment were fertile when tested on days 80 or 90 of drug administration. This may be attributable to extensive metabolism of tamoxifen to several active metabolites with different biological activities (Patterson et al, 1980). In fact, several investigators have demonstrated that women with breast cancer who are receiving tamoxifen therapy have very low steady-state concentrations of 4-hydroxytamoxifen in plasma, while $N$-desmethyl tamoxifen concentrations are about $50 \%$ higher than those of tamoxifen itself. According to Patterson et al. (1980), concentrations of tamoxifen in plasma were maximal $3 \mathrm{~h}$ after oral administration and steady state concentrations of tamoxifen and $\mathrm{N}$-desmethyl tamoxifen in plasma of healthy male volunteers were achieved at 4 and 7 days, respectively. Bowman et al. (1982) observed that the serum concentrations of tamoxifen and 4-hydroxytamoxifen in ovariectomized rats measured after a single dose of tamoxifen ( $7 \mathrm{mg} \mathrm{kg}^{-1}$ ) were maximal after $24 \mathrm{~h}$ and were undetectable by 4 days, at which time the nuclear and cytosol oestrogen receptor contents remained altered and were not restored to original values. According to Bowman et al. (1982), changes in oestrogen receptors after administration of tamoxifen may not only be simply related to the serum concentrations of tamoxifen and its metabolites, but also to the retention of ligand within the target tissue. Attempts are being made in our laboratory to measure tamoxifen and its metabolites in male rats treated with tamoxifen for varying periods.

Histological examination of treated testes showed marked disorganization of the cytoarchitecture of the tubule and obliteration of the lumen. The normal arrangement of germ cells and Sertoli cells was difficult to identify. Organization of the germ cells and cell associations which represent the stages of the seminiferous cycle could not therefore be correctly assessed. Microtubules of Sertoli cells play an important role in the main- tenance of the normal cytoskeleton of rat testis seminiferous epithelium and spermatogenesis (Allard et al., 1993). It is possible that the observed disorganization of the cytoarchitecture of the seminiferous tubule and impaired spermatogenesis may have been due to disturbed functioning of Sertoli cells. If this postulate is accepted, then why, how and what functions of Sertoli cells were actually altered remain to be elucidated. The changes induced by tamoxifen were completely reversed on drug withdrawal, which resulted in normalization of accessory sex organ weights, circulating concentrations of $\mathrm{LH}$ and testosterone, potency and fecundity of tamoxifen treated rats.

In summary, evidence is presented that tamoxifen at a particular dose range $\left(40-400 \mu \mathrm{g} \mathrm{kg}^{-1} \mathrm{day}^{-1}\right)$ affects the potency and fecundity of male rats reversibly, most probably without changes in mating behaviour. An effective hormonal contraceptive regimen for men has not yet been developed despite much work. A major impediment in the process has been the risk of a decrease or loss of libido owing to hormonal interception. The study reported here suggests that the potential of using tamoxifen for male contraception should be explored further.

Special reagents for radioimmunoassays were provided by the National Institutes of Health, Bethesda under Indo-US Agreement (No. 01-051) on Science and Technology. The authors acknowledge the valuable help of D. Balaiah, Senior Research Officer (Statistics) in statistical analyses of the data. The technical assistance of H. G. Pawar is acknowledged and S. V. Nair is thanked for typing this manuscript.

\section{References}

Ain-Melk Y, Belisle S, Carmel M and Jean-Pierre T (1987) Tamoxifen citrate therapy in male infertility Fertility and Sterility 48 113-116

Allard EK, Johnson KJ and Boekelheide K (1993) Colchicine disrupts the cytoskeleton of rat testis seminiferous epithelium in a stage-dependent manner Biology of Reproduction 48 143-153

Balasinor N, Gill-Sharma MK, Parte P and Juneja HS (1992) Cerebrospinal fluid and blood concentrations of luteinizing hormone, follicle stimulating hormone and prolactin following castration of rats Acta Endocrinologica 127 $58-65$

Bartke A, Mason M, Dalterio S and Bex F (1978) Effects of testosterone and gonadotrophins in the male rat journal of Endocrinology 79 239-240

Bhasin S, Fielder T, Peacock N, Sod-Moriah UA and Swerdloff RS (1988) Dissociating antifertility effects of $\mathrm{GnRH}$ antagonist from its adverse effects on mating behaviour in male rats American Journal of Physiology 254 E84-E91

Bowman SP, Leake A and Morris ID (1982) Hypothalamic, pituitary and uterine cytoplasmic and nuclear oestrogen receptors and their relationship to the serum concentration of tamoxifen and its metabolite, 4-hydroxy tamoxifen in the ovariectomized rat Journal of Endocrinology 94 167-175

Buckley MMT and Goa KL (1989) Tamoxifen: a reappraisal of its pharmacodynamic and pharmacokinetic properties and therapeutic use Drugs $37541-590$

David GFX, Herbet J and Wright GDS (1973) The ultrastructure of the pineal ganglion in the ferret Journal of Anatomy $11579-97$

Flickinger CJ (1977) Alterations in the male reproductive tract of rats treated with Clomiphene American Journal of Anatomy 149 533-562

Furr BJA and Jordan VC (1984) The pharmacology and clinical uses of tamoxifen Pharmacology and Therapeutics 25 127-205

Furr BJA, Patterson JS, Richardson DN, Slater SR and Wakeling AE (1979) Tamoxifen. In Pharmacological and Biochemical Properties of Drug Substances Vol. 2 pp 355-399 Ed. ME Goldberg. American Pharmaceutical Association, Washington

Harper MJK and Walpole AL (1967) A new derivative of triphenyl ethylene. Effect of implantation and mode of action in rats Journal of Reproduction and Fertility 13 101-119

Downloaded from Bioscientifica.com at 04/26/2023 01:25:09PM 
Heller GV and Heller CG (1970) Quantitation of normal and abnormal germinal cells following administration of clomiphene citrate in normal men Journal of Clinical Endocrinology and Metabolism 30 196-207

Jordan VC and Murphy CS (1990) Endocrine pharmacology of antiestrogens as antitumor agents Endocrine Reviews 11 578-610

Juneja HS, Karanth S, Dutt A, Parte P and Meherji PK (1991) Diurnal variations and temporal coupling of bioactive and immunoactive luteinizing hormone, prolactin, testosterone and $17 \beta$-estradiol in adult men Hormone Research 35 $89-94$

Kalra SP and Kalra PS (1983) Neural regulation of luteinizing hormone secretion in the rat Endocrine Reviews 4 311-335

Kalra SP and Prasad MRN (1967) Effect of Clomiphene on fertility in male rats Joumal of Reproduction and Fertility 14 39-48

Kamal N, Agarwal AK, Jehan Q and Setty BS (1985) Biological action of estrogen on the epididymis of prepubertal Rhesus monkey Andrologia 17 339-345

Kato J (1977) Steroid hormone receptors in brain, hypothalamus and hypophysis. In Receptors and Mechanism of Action of Steroid Hormones Part 2 pp 603-672 Ed. JR Pasqualini. Dekker, New York

Lin T, Murono EP, Osterman J and Nankin HR (1981) Direct inhibition of rat Leydig-cell function by tamoxifen Metabolism 30 156-159

McEwen BS (1975) Hormones, receptors and brain function Advances in Pathology 1 56-59

Muldoon TG (1977) Pituitary estrogen receptors. In The Pituitary, A Current Review pp 295-329 Ed. MB Allen and VB Mahesh. Academic Press, New York

Nakhla AM, Mather JP, Jaane OA and Bardin CW (1984) Estrogen and androgen receptors in Sertoli, Leydig, myoid and epithelial cells. Effect of time in culture and cell density Endocrinology 115 121-128

Nelson WO and Patanelli DJ (1962) Effect of clomiphene on testes and pituitaries of male rats Federation Proceedings 21 437-442

Noci I, Chelo E, Salatarelli O, Donaticori G and Scarselli G (1985) Tamoxifen and oligospermia Archives of Andrology 15 83-88

Orgebin-Crist MC, Danzo BJ and Davies J (1975) Endocrine control of the development and maintenance of sperm fertilizing ability in the epididymis. In Handbook of Physiology Vol 5 pp 319-338 Eds RO Greep and EB Astwood. American Physiological Society, Washington, DC
Parker LN, Gray DR, Lai MK and Levin ER (1986) Treatment of gynecomastia with tamoxifen: a double-blind crossover study Metabolism 35 705-708

Patterson JS, Settatree RS, Adam HK and Kemp JV (1980) Serum concentrations of tamoxifen and major metabolite during long-term Novadex therapy, correlated with clinical response. In Breast Cancer - Experimental and Clinical Aspects pp 89-92 Eds HT Mouridsen and T Palshof. Pergamon Press, Oxford

Robaire B, Ewing LL, Irby DC and Desjardins C (1979) Interaction of testosterone and estradiol-17 $\beta$ on the reproductive tract of the male rat Biology of Reproduction 21 455-463

Roy S, Mahesh VB and Greenblatt RB (1964) Effect of Clomiphene on the physiology of reproduction in the rat. 1. Changes in the hypophyseal-gonadal axis Acta Endocrinologica 47 645-656

Schally AV, Kastin AJ and Arimura A (1972) FSH-releasing hormone and LH-releasing hormone Vitamins and Hormones 30 84-164

Skinner MK (1991) Cell-cell interactions in the testis Endocrine Reviews 12 45-77

Sodersten P (1979) Role of estrogens in the display and development of sexual behaviour in male rats. In Endocrine Control of Sexual Behaviour pp 305-315 Ed. C Beyer. Raven Press, New York

Tekpetey FR and Amann RP (1988) Regional and seasonal differences in concentrations of androgen and estrogen receptors in ram epididymal tissue Biology of Reproduction 38 1051-1060

Van Beurden-Lamers WMO, Brinkman AO, Mulder E and Van der Molen HJ (1974) High affinity binding of oestradiol-17 $\beta$ cytosols from testis, intestinal tissue, pituitary, adrenal, liver and accessory sex glands of male rat. Biochemical Joumal $140495-502$

Vermeulin A. and Comhaire E. (1978) Hormonal effects of an antiestrogen, tamoxifen, in normal and oligospermic men Fertility and Sterility 29 320-327

Wantanabe M, Tanaka H, Koizumi H, Tanimoto Y, Toni R and Yanagita T (1980) General toxicity studies of tamoxifen in mice and rats Jitchuken Zenrinsho Kenkyicho 6 1-36

Willis KJ, London DR, Bevis MA, Butt WR, Lynch SS and Holder G (1977) Hormonal effects of tamoxifen in oligospermic men Joumal of Endocrinology 73 171-178 